Miha Marič', Mitja Jeraj²

${ }^{1}$ University of Maribor, Faculty of Organizational Sciences 2JPO d.o.o.Maribor

\title{
Educational Achievements as a Determinant of an Individual's Formal Power
}

UDC; 005.96 ; 005336.4

DOI: 10.7595/management.fon.2014.0022

XIV International Symposium SymOrg 2014, 06 - 10 June 2014, Zlatibor, Serbia

The scope of this study is to define how educational achievements of individuals in Slovenia define their "formal power" in the organizations where they work. The study is based on theoretical definitions of the concepts of formal power and education. A total of 509 people from Slovenia over 30 years of age participated in the study. We recognized a certain influence of educational achievement on the formal position in the organizational hierarchy. The main predictor of an individual's formal power in an organization is the individual's last achieved level of formal education. The average grade for the final achieved level of formal education and the initiative regarding the search for additional education has much less of an impact on power than the highest level of education obtained. One of the most important practical implications is that education is one of the basic predispositions to having formal power but not necessarily always and not in every case.

Keywords: education, formal power, work, employees, HRM

\section{Introduction}

The basic definition of power can be: "Power is the ability to implement one's will." The study of power in an organization has been an interesting topic for many researchers. Power is consider by many as one of the most important factors in an organization. Some authors suggest that power lies in the potential, and others suggest that power is only present in its use. There is also an ongoing debate what makes an individual powerful (Marič \& Ferjan, 2011).

Despite the importance of an individual's formal and informal power in an organization, there is very little research on what gives power, formal or informal combined, to an individual in an organization. In this article, we will explore the effect of an individual's education on one's formal power in an organization. We suppose that the education one receives leads to principal differences in one's power later on in the organization that one works in. We can also say that the duration of schooling determines one's formal power in an organization. Those who have higher education usually gain more formal power and amenities depending on their working positions in some cases even regardless of their abilities.

In his book "Organization, Power and Change" (1995) Borum Finn states that there is reason to believe that the close connection between educational and professional competence and pyramidal location plays an important role. It creates the impression that there is a connection between the length of education and the ability to make decisions also in relation to non-professional issues. The inflexibility of the educational system widens the individual pyramidal strata and thus reinforces the authoritarian nature of the system. Education is one of the identified factors that contribute to one's personal power (Rees, 1999). One can argue that the shift from a capital-based to a knowledge-based economy represents a fundamental shift in power dynamics (Lynn, 2000).

\section{An Individual's Education}

The educational process offers individuals knowledge, skills and habits. Some describe it as the last level of education that one has achieved so far in their life (FAQ | Ministry of Higher Education, Science and Tech- 
nology, 8.6.2009). the number of years of education one has and what their average grade was during the last level of their education may also be important. Knowledge is the capacity to act on information... it implies learning (Lynn, 2000). We can say that education is one of the predispositions to attaining knowledge, but not in everyone's case. Being included in the educational process does not necessarily mean that the individual has really gained that knowledge. Organizations employ the most educated workforce in the history of the world (Burke \& $\mathrm{Ng}, 2006$ ) because they do not need more people willing to blindly follow orders or do repetitive work; they need people of courage and initiative (Pinchot, 1992).

Different styles of upbringing have their effect on children's will and capacity to learn, and on their adaptability to the requirements of the school (Ferjan \& Jereb, 2008). Bowles and Gintis (2002) found that parental economic status is passed on to children in part by means of unequal opportunity, but that the economic advantages of the offspring of higher status families go considerably beyond the superior education they receive. Educational transformation also influences the social justice and the social status of the people (Unterhalter \& Dutt, 2001). There are also various factors that influence the study progress (Jereb et al., 2009).

By the day, more and more importance is given to lifelong learning (European Commission - Education \& Training - lifelong learning programme - A single umbrella for education and training programmes, 2009) in which the formal education is in a way perceived as a foundation for further lifelong work and education. It can easily be said that the higher level of formal education one has, the more involved in lifelong learning one has to be to keep up with everyday requirements of one's work (Ferjan \& Jereb, 2005).

Lifelong learning (European Commission - Education \& Training - lifelong learning programme - A single umbrella for education and training programmes, 2009) is in a way defined by additional learning per year, search for appropriate forms of additional education and of course, not to forget, the training that is required by the employers or the organization in which one works. The learning process accompanies individuals in every phase of their life. The levels of education in the EU are also increasing with the generations that follow (The levels of education in the EU are increasing with the following generations: Evropa.gov.si, 8.6.2009).

\section{An Individual's Formal Power}

Power is part of our lives, both private and organizational. Power is basically the ability to influence the desired outcomes. Power can be broadly defined as the ability to influence different outcomes, by pooling resources (human and material) to achieve the realization of certain things within the network of relationships (Rees, 1999) and at the same time to resist unwanted influence from others (Wagner \& Hollenbeck, 2010). Individuals who have power in the organizational environment often have power in their private lives and vice versa.

An individual's power in an organization can be best assessed with observations (Finn, 1995). However, on the other hand, that is a long process, sometimes even subjective and would take a lot of man-hours to implement on a larger sample. That is why the power evaluating process takes part only on smaller samples at a time; for instance, one company or one branch of a company at a time. Robbins (quoted in: Senior, 2002) argues: "Power has been described as the last dirty word... People who have it deny it, people who want it try not to appear to be seeking it, and those who are good at getting it are secretive about how they got it."

An individual's power is also very relative; one could have it one day and lose it on another (Mintzberg, 1983). Or one could have power in one group, and have none in another group of people simultaneously. Power is difficult to measure, since it can only be perceived (Marič \& Ferjan, 2011). From the social-psychological perspective, a person's behaviour is affected by his or her behavioural intentions, which are in turn influenced by an attitude and set of perceptions. Behavioural intention is regarded as a key antecedent in determining one's future behaviour (Wu et al., 2008). We can argue that power concerns the capacity of individuals to exert their will over others.

In a company or in an organization there are basically two kinds of power: formal and informal power (Mintzberg, 1983). While formal power is defined, the informal power that is in many cases even more important is not so well defined. Here we will focus on individual's formal power within organizations. 
The formal power comes from one's place in the hierarchy, one's duties and their position and is well defined. Hierarchical levels are adjusted to convey the relative authority of employees (Rosenbaum, 1980). Power resides in the position no matter who has it (Moorhead \& Griffin, 2010) so it is similar to authority. When constructing a position in an organization the power of this position is determined. The person in this position has all the power and all the limitations that the position holds. The formal power on an individual level consists of: legitimate power, reward power, coercive power and information power (George \& Jones, 2008). The formal power basically comes from placement in the organizational hierarchy.

\section{Research Questions}

Below we will explore the influence of one's formal level of education with respect to an individual's formal power in an organization. A higher level of formal education is considered to be a way of getting everything that one wants in life (often climbing the hierarchical ladder) and the thing that many consider as the cover of it all is power. There are several ways to gain power, and one of the most commonly perceived ways is education. For instance, when one introduces himself as a $\mathrm{PhD}$, all, or at least a vast majority of people around him think that he knows everything. Hogan (2005) claims that people respect someone who has a higher position (M.D. vs. orderly), more extensive education (Ph.D. vs. high school), and more experience (20 years of work experience vs. just out of school). That brings us to our research questions.

- R1: What kind of effect does individual's higher level of formal education have on individual's formal power in the organization?

- R2: What kind of positions do individuals achieve in the hierarchy of an organization compared to their achieved level of formal education?

\section{Methodology}

Participants in this study were selected randomly. The sample consisted of 232 men and 277 women $(\mathrm{N}=509)$. The age range of the respondents was between 30 and 61 years. The average age of the respondents was 41.35 years, the average level of education was 5.26 (a little above completed high school), and the average place in the organization's hierarchy was 3.50 (middle administrative staff).

The questionnaire contained closed questions referring to: (i) general data (age, gender), (ii) education, (iii) an individual's formal power within an organization. An individual's formal power was measured through their place in the hierarchy of the organization. Individuals were asked about their place in the hierarchy of the organization that they work in. We have developed and used the following hierarchical scale: (1) manual worker, (2) head of the shift, (3) routine administrative staff, (4) non-routine administrative staff, (5) expert, (6) lower management, (7) middle management, (8) top management.

The final "hierarchical" structure of the sample is shown in Table 1. We have developed a concept to classify the placements in the hierarchy ourselves and created eight degrees of hierarchical placement of individuals in the organization's hierarchy which relate to their formal power.

Table 1: Placement in the Organization's Hierarchy $(n=509)$

\begin{tabular}{|c|c|c|c|c|c|c|c|c|c|}
\hline 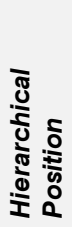 & 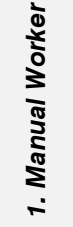 & 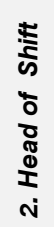 & 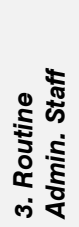 & 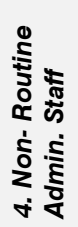 & 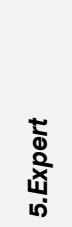 & 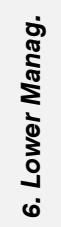 & 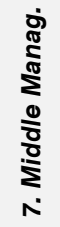 & $\begin{array}{l}\frac{8}{8} \\
\sum_{0}^{\pi} \\
\sum_{\infty}^{0} \\
\frac{0}{0}\end{array}$ & $\begin{array}{l}\bar{\Xi} \\
\text { 。 }\end{array}$ \\
\hline$N$ & 164 & 43 & 76 & 38 & 84 & 32 & 38 & 34 & 509 \\
\hline$\%$ & 32.2 & 8.4 & 14.9 & 7.5 & 16.5 & 6.3 & 7.5 & 6.7 & 100 \\
\hline
\end{tabular}

Mean $=3.50 ;$ Median = 3.00; Std. Deviation = 2.303; 
The individual's final level of formal education was measured through the achieved degree of education. The following scale was used: (1) did not finish elementary school, (2) finished elementary school (8 years), (3) secondary school (2 years), (4) secondary school (3 years), (5) secondary school (4 years), (6) two year study, (7) higher education, and (8) master's degree, doctorate degree. The final formal educational structure of the sample is shown in Table 2. In Slovenia, the education classification from 1980 is used and has eight degrees (Ferjan \& Jereb, 2008).

Table 2: Formal educational structure $(n=509)$

\begin{tabular}{|l|r|r|r|r|r|r|r|r|r|}
\hline $\begin{array}{l}\text { Education } \\
\text { degree }\end{array}$ & $\mathbf{1}$ & $\mathbf{2}$ & $\mathbf{3}$ & $\mathbf{4}$ & $\mathbf{5}$ & $\mathbf{6}$ & $\mathbf{7}$ & $\mathbf{8}$ & Total \\
\hline $\mathbf{N}$ & 6 & 41 & 20 & 74 & 159 & 60 & 112 & 37 & 509 \\
\hline$\%$ & 1.2 & 8.1 & 3.9 & 14.5 & 31.2 & 11.8 & 22.0 & 7.3 & 100 \\
\hline
\end{tabular}

Mean = 5.26; Median = 5.00; Std. Deviation = 1.67;

The educational success at the last level of formal education was measured on a grading scale from 6 to 10 , where: (6) = sufficient, (7) = good, (8) = very good, (9) = almost excellent and (10) = excellent which is in use by Slovenian universities. Primary and secondary schools in Slovenia use a grade scale from 1 to 5 , because of which the grades from 1 to 5 were converted into grades ranging from 1 to 10 as follows: 1 converted into 5; 2 converted into 6; 3 converted into 7; 4 - 4,5 converted into 8; 4,5 - 4,75 converted into 9; 4,75 -5 converted into 10 .

Table 3: Average Grade at the Last Educational Level $(n=509)$

\begin{tabular}{|l|r|r|r|r|r|r|}
\hline $\begin{array}{l}\text { Average } \\
\text { grade }\end{array}$ & $\begin{array}{r}\mathbf{6}- \\
\text { Sufficient } \\
(\mathbf{6 , 0 0 - 6 , 9 9 )}\end{array}$ & $\begin{array}{r}\mathbf{7 - G o o d} \\
\mathbf{( 7 , 0 0 - 7 , 9 9 )}\end{array}$ & $\begin{array}{r}\mathbf{8} \text { - Very } \\
\text { Good } \\
(\mathbf{8 , 0 0 - 8 , 9 9 )}\end{array}$ & $\begin{array}{r}\mathbf{9} \text { - Almost } \\
\text { Excellent } \\
\mathbf{( 9 , 0 0 - 9 , 4 9 )}\end{array}$ & $\begin{array}{r}\text { 10- } \\
\text { Excellent } \\
\mathbf{( 9 , 5 0 - 1 0 , 0 0 )}\end{array}$ & Total \\
\hline Frequency & 48 & 199 & 181 & 53 & 28 & 509 \\
\hline Percent & 9.43 & 39.10 & 35.56 & 10.41 & 5.50 & 100 \\
\hline
\end{tabular}

Mean = 7.7055; Median = 8.00; Std. Deviation = 0.96477;

Self-initiative regarding the search for additional training was measured through surveying the respondents as to how often they search for appropriate additional forms of education and training. A grading scale from 1 to 5 was used, where: (1) = never, (2) $0=$ very rarely, (3) = occasionally, (4) = often and (5) = permanently.

Table 4: Self-initiative Regarding the Search of Appropriate Education or Training Contents $(n=509)$

\begin{tabular}{|l|r|r|r|r|r|r|}
\hline $\begin{array}{l}\text { Self-initiative } \\
\text { Regarding } \\
\text { Education }\end{array}$ & $\mathbf{1}$ - Never & $\begin{array}{r}\text { 2- Very } \\
\text { Rarely }\end{array}$ & $\begin{array}{r}\text { 3 - } \\
\text { Occasionally }\end{array}$ & 4- Often & 5 - Permanently & Total \\
\hline Frequency & 126 & 130 & 149 & 76 & 28 & 509 \\
\hline Percent & 24.8 & 25.5 & 29.3 & 14.9 & 5.5 & 100 \\
\hline
\end{tabular}

Mean $=2.51 ;$ Median = 2.00; Std. Deviation = 1.173;

\section{Results and Discussion}

We can see that there are positive correlations between all of the variables. All the variables were measured on an increasing scale. As seen in the table above there is a positive correlation between the achieved level of education and all of the positions in the hierarchical structure that we used as a measure of formal power in an organization are above 0,304 and are all statistically significant. Table 5 gives the correlation coefficients between the previously described variables. 
Table 5: Pearson R Correlation Coefficients $(n=509)$

\begin{tabular}{|r|r|r|r|}
\hline & $\begin{array}{r}\text { Achieved level } \\
\text { of education }\end{array}$ & $\begin{array}{r}\text { Average grade } \\
\text { at the last level } \\
\text { of education }\end{array}$ & $\begin{array}{r}\text { Self-initiative regarding } \\
\text { the search for additional } \\
\text { education or training }\end{array}$ \\
\hline $\begin{array}{r}\text { Average grade at the last } \\
\text { level of education }\end{array}$ & $0.332^{*}$ & & \\
\hline $\begin{array}{r}\text { Self-initiative regarding } \\
\text { the search for additional } \\
\text { education or training }\end{array}$ & $0.488^{*}$ & & \\
\hline $\begin{array}{r}\text { Place in the hierarchical } \\
\text { structure }\end{array}$ & $0.628^{*}$ & $0.304^{*}$ & \\
\hline
\end{tabular}

* Correlation is significant at the 0.01 level (2-tailed).

To continue, a regression analysis between the independent variables (Achieved level of formal education, Average grade at the last level of formal education and Self-initiative regarding the search for additional education or training) and the dependent variable (Place in the hierarchical structure) has been made and is shown in Table 6 below.

Table 6: Regression Analysis for the Dependent Variable "Place in the Hierarchical Structure" $(n=509)$

\begin{tabular}{|c|c|c|c|c|c|}
\hline \multirow[t]{2}{*}{ Predicators } & \multicolumn{2}{|c|}{ Unstandardized Coefficients } & \multirow{2}{*}{$\begin{array}{r}\begin{array}{r}\text { Standardized } \\
\text { Coefficients }\end{array} \\
\text { Beta }\end{array}$} & \multirow[t]{2}{*}{$t$} & \multirow[t]{2}{*}{ Sig. } \\
\hline & B & Std. Error & & & \\
\hline (Constant) & -2.790 & .621 & & -4.495 & .000 \\
\hline Achieved Level of Education & .684 & .054 & .498 & 12.564 & .000 \\
\hline $\begin{array}{l}\text { Average Grade at the Last } \\
\text { Level of Education }\end{array}$ & .218 & .085 & .091 & 2.567 & .011 \\
\hline Self-Initiative Regarding Education & .402 & .075 & 205 & 5.323 & .000 \\
\hline
\end{tabular}

Dependent Variable: Place in the Hierarchical Structure

With the predictors "Achieved Level of Formal Education", "Average Grade at the Final Level of Formal Education", "Self-initiative Regarding the Search for Additional Education and Training" the $43.3 \%$ variance of "Place in the hierarchical structure" is explained. The achieved level of formal education $(\square=0.498)$ has the most influence. Individuals educated differently have different abilities of reaching higher positions in the hierarchical structure which answers $R 1$.

The answer to $R 2$ lies in Table 7 where we can see that not even one individual who has not completed primary school achieved a position in the hierarchy higher than the position of manual worker. On the other hand, $35.15 \%$ of the individuals who achieved the highest level of formal education also achieved the top management positions in organizations and $94.6 \%$ of the achieved positions in the hierarchy that are at the level of experts or management $(r=0.628$ at $p=0.01)$. 
Table 7: An Individual's Position in the Hierarchy Compared to an Individual's Achieved Level of Formal Education $(n=509)$

\begin{tabular}{|c|c|c|c|c|c|c|c|c|c|c|}
\hline & & \multicolumn{8}{|c|}{ Position in the Hierarchy } & \multirow[t]{2}{*}{ Tota } \\
\hline & & $\begin{array}{l}\text { Manual } \\
\text { Worker }\end{array}$ & $\begin{array}{r}\text { Head of } \\
\text { Shift }\end{array}$ & $\begin{array}{r}\text { Routine } \\
\text { Admin. } \\
\text { Staff }\end{array}$ & $\begin{array}{l}\text { Non- } \\
\text { routine } \\
\text { Admin. } \\
\text { Staff }\end{array}$ & Expert & $\begin{array}{c}\text { Lower } \\
\text { Manag. }\end{array}$ & $\begin{array}{c}\text { Middle } \\
\text { Manag. }\end{array}$ & $\begin{array}{r}\text { Top } \\
\text { Manag. }\end{array}$ & \\
\hline \multirow{8}{*}{ 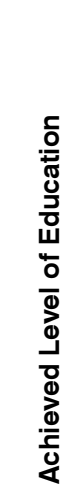 } & 1 & $100.0 \%$ & & & & & & & & $100.0 \%$ \\
\hline & 2 & $85.4 \%$ & $2.4 \%$ & $2.4 \%$ & & $7.4 \%$ & & & $2.4 \%$ & $100.0 \%$ \\
\hline & 3 & $75.0 \%$ & $15.0 \%$ & $5.0 \%$ & $5.0 \%$ & & & & & $100.0 \%$ \\
\hline & 4 & $62.2 \%$ & $16.1 \%$ & $4.1 \%$ & $10.8 \%$ & $4.1 \%$ & $1.4 \%$ & & $1.4 \%$ & $100.0 \%$ \\
\hline & 5 & $28.3 \%$ & $13.8 \%$ & $27.0 \%$ & $10.2 \%$ & $8.8 \%$ & $5.0 \%$ & $3.1 \%$ & $3.8 \%$ & $100.0 \%$ \\
\hline & 6 & $20.0 \%$ & $3.3 \%$ & $16.7 \%$ & $6.7 \%$ & $25.0 \%$ & $15.0 \%$ & $10.0 \%$ & $3.3 \%$ & $100.0 \%$ \\
\hline & 7 & $4.5 \%$ & $2.7 \%$ & $14.3 \%$ & $8.0 \%$ & $32.1 \%$ & $10.7 \%$ & $17.9 \%$ & $9.8 \%$ & $100.0 \%$ \\
\hline & 8 & & & $5.4 \%$ & & $35.15 \%$ & $5.4 \%$ & $18.9 \%$ & $35.15 \%$ & $100.0 \%$ \\
\hline Total & & $32,2 \%$ & $8.4 \%$ & $14.9 \%$ & $7.5 \%$ & $16.5 \%$ & $6.3 \%$ & $7.5 \%$ & $6.7 \%$ & $100.0 \%$ \\
\hline
\end{tabular}

1 - did not finish primary school. 2 - finished primary school. 3 - secondary school (2 years). 4 - secondary school (3 years). 5 - secondary school (4 years). 6- two year study. 7 - higher education. 8 - master's degree. doctorate degree

Of course, characteristics do not fit every single individual but we still think that people who have achieved higher levels of formal education also have higher tendencies toward the top of the hierarchical structure and also have better possibilities of achieving higher positions.

\section{Conslusion}

An individual's power is an ever-important factor in one's personal as well as one's business life. Education is a factor in one's power yet the mere presence of formal education will not give you power as many believe. This study provides basic insights into the connection between one's formal education and power and it can be summarized as follows: an individual's formal education is one of many things that are components of an individual's formal power. However, this does not explain the whole concept of power because there is an infinite number of variables that influence one's power and we can only explain them in parts.

Several limitations of this study need to be considered before interpretations of the results can be explored. First, the discussed findings and implications were obtained from a single study; generalizing the results should be done with caution. Second, the whole research was focused mostly on how an individual's education affects their formal power. We have had that in mind already in the beginning when we were to define the goal of the study so that it is relatively simple with a concept that is influenced by many other variables that are not included in this study.

We can all agree that there is a lot more to power that just these variables that we used in our study to determine it, however, even this simple study shows that there are some basic predispositions to having formal power and that one of them is formal education. Maybe in a way the findings are a specific area because formal education is so emphasized in this study. However, it is still an interesting way for evaluating (in a simplified way) one's potential power depending on formal education. 
One of the factors that influence an individual's power could also be the power of their parents and their social position. A similar study regarding the influence of the social class position as a determinant of educational achievements has already been done (Ferjan \& Jereb, 2008) and the results could also be used to determine power and its sources.

According to the findings, the perceptions and the "size" of an individual's formal power in an organization depend on one's level of formal education. One man once said that all people are divided into two groups: the leaders and the followers. Most people are simple followers but those who want to be leaders need power to achieve so that someone will follow them. Leadership facilitates quality relationships and balances power (Pinchot, 1992).

\section{REFERENCES}

[1] Bowles, S., \& Gintis, H. (2002). Schooling in Capitalist America Revisited.Sociology of Education, 75(1), 1-18.

[2] Burke, R. J.,\& Ng, E. (2006). The changing nature of work and organizations: Implications for human resource management.Human Resource Management Review, 16, 86-94.

[3] European Commission - Education \& Training - lifelong learning programme - A single umbrella for education and training programmes. Found on June $8^{\text {th }} 2009$ on web address http://ec.europa.eu/education/lifelong-learning-programme/doc78 en.htm (8.6.2009)

[4] Ferjan, M., \& Jereb, E. (2008). Social Class Position as a Determinant of Educational Achievement.Društvena Istraživanja, 17(4-5), 869-886. doi: 316.342.2(497.4):37

[5] Jereb, E., Ferjan, M., \& Jesenko, J. (2009). Conceptual Model of Study Progress in Higher Education.Didactica Slovenica - Pedagoška obzorja, 24(1), 168-184. doi: 37.091.212.7

[6] Finn, B. (1995). Organization. Power and Change. Handelshøjskolens Forlag, Copenhagen, ISBN 9788716132482.

[7] George, J. M.,\& Jones, G. R. (2008). Understanding and managing organizational behavior. (5 $5^{\text {th }}$ ed.). Upper Saddle River: Pearson Education, Inc.

[8] Hogan, K. (2005). The science of influence: how to get anyone to say »yes « in 8 minutes or less! Hoboken, New Jersey, John Wiley \& Sons. Inc.

[9] Lynn, I. (2000). Knowledge, Labour and Education.Compare, 30(3), 275-282.

[10] Marič, M.,\& Ferjan, M. (2011). Managing with power in the organisation to achieve common progress. T. Kern \& V. Rajkovič (eds), People and sustainable organization, Frankfurt am Main, Peter Lang, ISBN 978-3-631-62113-4.

[11] Mintzberg, H. (1983).Power in and Around Organizations. Englewood Cliffs, Prentice Hall.

[12] Moorhead, G., \& Griffin, R. W. (2010). Organizational Behavior: Managing People and Organizations. $\left(9^{\text {th }}\right.$ ed.). South-Western: Cengage Learning.

[13] Pinchot, E. S. (1992). Balance the Power.Executive Excellence, 9(9), 3-5.

[14] Rees, R. (1999). Power: an example of its changing nature.The Canadian Journal of Higher Education, 29(1), 27-46.

[15] Rosenbaum, J. E. (1980). Hierarchical and Individual Effects on Earnings.Industrial Relations, 19(1), 114.

[16] Senior, B. (2002). Organisational change, Harlow, Prentice Hall.

[17] Unterhalter, E., \& Dutt, S. (2001). Gender, Education and Women's Power: Indian state and civil society intersections in DPEP (District Primary Education Programme) and Mahila Samakhya.Compare, 31(1), 57-73.

[18] Wagner, J. A. III,\& Hollenbeck, J. R. (2010). Organizational Behavior: securing competitive advantage. Routhledge, New York, ISBN 0-203-87353-X.

[19] Wu, W., Chang, H. P., \&Guo, C. J. (2008). An Empirical Assessment of Science Teachers' Intentions toward Technology Integration.The Journal of Computers in Mathematics and Science Teaching, 27(4), 499-520.

Receieved: June 2014. Accepted: September 2014. 


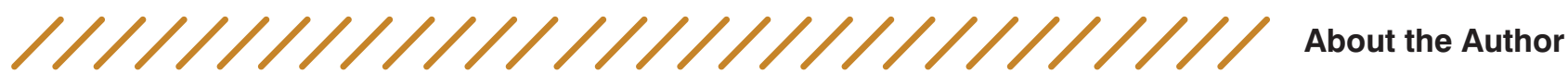

\section{Miha Marič \\ University of Maribor, Faculty of Organizational Sciences miha.maric@fov.uni-mb.si}

Miha Marič, Ph.D., is a researcher in the area of leadership, management, and organizational sciences. He is currently employed as a teaching assistant at the University of Maribor's Faculty of Organizational Sciences and has a Ph.D. from the Faculty of Economics, University of Ljubljana. His research interests are power, leadership, organizational behavior, HRM, management, organization.

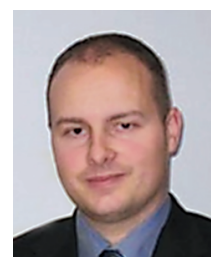

Mitja Jeraj 2 JPO d.o.o.Maribor mitja.jeraj@hotmail.com

Mitja Jeraj, Ph.D., is a researcher in the area of entrepreneurship, management, and organizational sciences. His main research interests include entrepreneurship as a broad field of research, entrepreneurial personalities, relations between entrepreneurship and economic growth, relations between entrepreneurship and

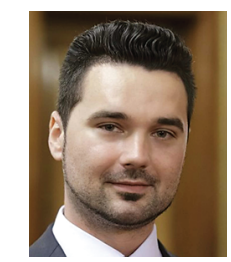
unemployment, connection between entrepreneurship and development of different sectors (e.g. sport) etc. His research also focuses on management in small and medium enterprises, on cost management, on development of the organization over time and on the educational system. 